\title{
Gambaran Identitas Etnis Remaja Suku Jawa dan Sunda
}

Aqiila Fathurroja, Humaira Mumtazah, Rosiana, Siti Barkah Miarti Pudoli, Fridayanti UIN Sunan Gunung Djati, Jl. AH Nasution No.105 Bandung

e-mail: fridayanti90@gmail.com

\begin{tabular}{|c|c|}
\hline Abstract / Abstrak & Keywords / Kata kunci \\
\hline $\begin{array}{l}\text { Ethnic identity is important in cultural inheritance. In border areas, there are } \\
\text { often mixing of two different ethnic groups. The purpose of this study is to obtain } \\
\text { an overview of the ethnic identity of Sundanese and Javanese adolescents in the } \\
\text { border region. The subjects in this study were two group of students from one } \\
\text { High school in Ciamis, a border area between West Java and central Java. They } \\
\text { were members of the Javanese and Sundanese ethnic groups }(N=60) \text {. The } \\
\text { instrument used is the Multigroup Ethnic Identity Measure (MEIM) scale } \\
\text { developed by Phinney (1992). Result shows that the two ethnic groups have } \\
\text { almost the same sense of ownership, but they are low in exploring their ethnicity. }\end{array}$ & $\begin{array}{l}\text { Ethnic identity } \\
\text { Adolescence } \\
\text { Ownership } \\
\text { Exploration }\end{array}$ \\
\hline $\begin{array}{l}\text { Identitas etnis adalah hal penting dalam pewarisan budaya. Di wilayah perbatasan } \\
\text { sering terjadi pencampuran dua etnis yang berbeda. Tujuan penelitian ini adalah } \\
\text { memperoleh gambaran mengenai identitas etnis remaja Sunda dan Jawa di } \\
\text { wilayah perbatasan. Subjek dalam penelitian ini adalah siswa-siswi dari satu } \\
\text { sekolah di wilayah Ciamis, sebuah wilayah antara perbatasan Jawa Barat dan } \\
\text { Jawa Tengah. Subjek penelitian terbagi menjadi dua kelompok yaitu siswa yang } \\
\text { merupakan anggota dari etnis suku Jawa dan suku Sunda (N=60). Alat ukur yang } \\
\text { digunakan adalah skala Multigroup Ethnic Identity Measure (MEIM) yang } \\
\text { dikembangkan Phinney (1992). Hasilnya, kedua etnis tersebut memiliki rasa } \\
\text { kepemilikan yang hampir sama tingginya, namun mereka rendah dalam } \\
\text { mengeksplorasi etnisnya. }\end{array}$ & $\begin{array}{l}\text { Identitas Etnis } \\
\text { Remaja } \\
\text { Kepemilikan } \\
\text { Eksplorasi }\end{array}$ \\
\hline
\end{tabular}

\section{Pendahuluan}

Indonesia begitu kaya akan ragam budaya. Berdasarkan data sensus BPS tahun 2010 tercatat ada sekitar 1,340 suku bangsa atau etnis di Indonesia. Etnik sering diartikan sebagai himpunan manusia (subkelompok manusia) yang dipersatukan oleh suatu kesadaran atas kesamaan sebuah kultur atau sub-kultur tertentu, atau karena kesamaan ras, agama, asal usul daerah atau bangsa, bahkan peran atau fungsi tertentu. Setiap etnis menunjukkan keunikan dan ciri khas budaya tersendiri, menjadikan Indonesia sebagai negara dengan tingkat keragaman yang tinggi. Keragaman ini perlu dilestarikan karena menyangkut kekayaan bangsa.

Identitas etnis sering diartikan sebagai suatu ciri khas yang dimiliki oleh sekelompok orang yang dianggap sebagai inti dari diri mereka. Studi terkait identitas etnik sangat menarik dan perlu dilakukan terutama terkait dengan pewarisan budaya dan bahasa warisan. Banyak studi menemukan bahwa terdapat hubungan yang positif antara identitas etnis dan kefasihan bahasa warisan (Phinney, Romero, Nava, \& Huang, 2001).

Identitas budaya dijelaskan melalui tingkah laku, nilai, gaya interaksi serta budaya yang bersifat material. Adapun dimensi dari simbol etnis diantaranya adalah identifikasi etnis, yaitu perasaan memiliki terhadap kelompok, sebuah pengenalan dan keikatan dengan simbol budaya dan penanda bahasa (Becker, 1990).

Identitas telah lama dikenal sebagai tugas utama remaja. Pembentukan identitas adalah tugas perkembangan yang meningkat kepentingannya selama masa remaja saat mereka mulai mempertanyakan siapa dirinya (Erikson, 1968). Identitas diperoleh melalui proses eksplorasi alternatif dan komitmen namun perkembangan identitas bukan semata hanya proses individual. Diperolehnya identitas 
adalah hasil dari sejarah personal seseorang serta tempatnya dalam sejarah tersebut (Erickson, 1975). Menurut Erikson (1968), latar belakang budaya serta identitas seseorang sangat penting bagi pembentukan identitas seseorang. Studi mengenai identitas adalah spesialisasi yang sulit karena prosesnya berlokasi pada inti individu dan juga pada inti dari budaya kulturnya (Erikson, 1968).

Di sisi lain studi menunjukkan bahwa pengaruh sosial terhadap identitas etnis tampaknya tidak terjadi pada semua kelompok etnis. Studi yang dilakukan oleh Feuerverger (1991) menemukan variasi identitas etnis pada kelompok Italian, Portugis, China, Korea, Jepang dan Yahudi yang belajar pada universitas di Kanada. Mahasiswa Yahudi ditemukan memiliki identitas etnis yang tinggi sementara mahasiswa Jepang sebagai yang paling rendah. Namun, penjelasan mengenai perbedaan ini belum ditemukan (Feuerverger, 1991) .

Studi lain terkait budaya dan percampuran budaya menunjukkan bahwa mahasiwa Korea yang telah tinggal di Amerika sejak kecil mengidentifikasikan diri mereka sebagai orang Amerika, namun hal yang mereka sadari bahwa mereka bukan 'sepenuhnya Amerika' karena perbedaan fisik yang tampak jelas (Brown, 2009).

Penelitian lain juga menemukan hal yang mirip, dimana anak Portugis di New England, Amerika memiliki identitas yang ambivalen, artinya mereka menampilkan diri sebagai anak Amerika ketika di sekolah namun menampilkan diri sebagai etnis Portugis ketika di keluarganya karena orangtuanya tidak fasih berbahasa Inggris dan tidak mengikuti budaya Amerika (Becker, 1990)

Keragaman dalam satu bangsa ini memungkinan ada kelompok etnis berbeda yang saling berinteraksi di dalam satu wilayah seperti di wilayah perbatasan. Kabupaten Ciamis adalah salah satu kabupaten di Jawa Barat yang mayoritas penduduknya berbahasa Sunda. Letak geografis Ciamis berbatasan dengan Jawa Tengah, sehingga dapat kita temukan dialek yang berbeda. Kabupaten
Ciamis memiliki 197 desa yang terletak dan tersebar di wilayah Ciamis, mungkin kita akan mendapatkan atau menemukan perbedaan dialek di berbagai desa tersebut. Dari total 197 desa, 16 desa diantaranya berbatasan langsung dengan Jawa Tengah (Sanjaya, 2012).

Sebagai contoh, di satu kelurahan di wilayah Ciamis yang merupakan perbatasan antara Jawa Barat dan Jawa Tengah, terdapat beberapa dusun yang terdiri dari dua etnis berbeda, yaitu etnis Sunda dan Jawa. Para warga dari dua etnis tersebut setiap harinya berinteraksi, dalam kegiatan bertetangga, pembangunan desa, perbaikan jalan, atau acara pengajian. Para remaja bersekolah di tempat yang sama dan berbaur dengan teman selain etnisnya sendiri. Uniknya, dalam ketercampuran etnis ini, mereka masih tetap mempertahankan bahasa dan budaya etnisnya masingmasing. Orang suku Sunda menggunakan bahasa Sunda, begitu pun orang suku Jawa menggunakan bahasa Jawa. Orang Jawa juga masih melakukan tradisi among-among untuk memperingati ulang tahun pertama anaknya.

Berdasarkan hal ini peneliti tertarik untuk meneliti bagaimana remaja dari kedua etnis, yaitu suku Sunda dan Jawa membentuk identitas etnik mereka. Penelitian pada remaja dilakukan mengingat pada masa ini adalah masa pencarian identitas. Data ini diperlukan untuk mengetahui sejauhmana mereka mengeksplorasi dan berkomitmen terhadap etnisnya. Studi tentang identitas etnis sangat diperlukan karena pelestarian budaya dan bahasa di Indonesia.

\section{Pengertian Identitas}

Identitas adalah konsep yang kompleks dan multifacets, dibentuk dari banyak faktor seperi orientasi agama, budaya, pendidikan, pengaruh komunitas, nilai keluarga, dan sistem keyakinan (Myhill, 2003)

Pengertian identitas merujuk pada cara individu memahami dirinya sendiri dan dikenal oleh orang lain. Terdapat tiga bentuk identitas. Pertama, identitas pribadi (personal identity), mengacu pada kualitas dan atribut yang membedakan dirinya dari orang lain. Kedua 
identitas relasi (relational identity), mengacu pada kualitas diri kita dalam hubungan dengan orang lain. Terakhir, identitas kolektif (collective identity), mengacu pada pengakuan kita bahwa kita milik kategori-kategori sosial, seperti pekerjaan, agama, atau budaya.

\section{Identitas Sosial}

Identitas sosial adalah ciptaan kognitif dari pikiran manusia. Identitas sosial penting karena memenuhi kebutuhan universal untuk menjadi anggota kelompok sosial. Identitas personal dan sosial adalah dua hal yang berbeda namun tidak dapat terpisahkan, karena seseorang tidak dapat dipisahkan dari lingkungan sosial (Tajfel \& Turner, 1986). Mula-mula orang mengkategorisasikan diri sebagai anggota kelompok tertentu, kemudian mengidentifikasi dirinya dalam kelompok tersebut. Ini artinya mereka mengidentifikasi dirinya dalam kelompok tersebut. Sehingga ketika mempertimbangkan identitas, seseorang akan mempertimbangkan baik perspektif personal dan sosial.

Ini terjadi karena manusia memiliki kebutuhan akan afiliasi. Terpenuhinya kebutuhan ini membantu kita menciptakan hubungan yang bermakna. Dengan demikian pada awalnya muncul kebutuhan mendasar untuk berafiliasi dengan orang lain Selanjutnya mengarah ke kebutuhan kedua untuk memiliki kelompok sosial. Keanggotaan dalam kelompok akan membantu individu lebih sehat dan bahagia karena salah satu kebutuhan untuk berafiliasi terpenuhi. Kelak, perasaan seseorang mengenai identitas akan mempengaruhi bagaimana seseorang bertindak. Studi sebelumnya menunjukkan bahwa individu yang diterima di kelompok sosial mempunyai konsekuensi fisik dan psikologis yang lebih baik; mereka yang ditolak oleh kelompok sosial memiliki konsekuensi lebih negatif. Individu yang diacuhkan dan diisolasi sering mengalami berbagai macam tekanan (Baumeister, Nathan Dewall, Ciarocco, \& Twenge, 2005).

\section{Metode Penelitian}

Penelitian ini menggunakan pendekatan metode deskriptif kuantitatif dengan variabel identitas etnik, yaitu etnis Sunda dan Jawa. Peneliti mengambil subjek penelitian dari siswa-siswi MAN 4 Ciamis yang terdiri dari 30 orang suku Jawa dan 30 orang suku Sunda dengan kriteria: a) anggota etnis Jawa atau Sunda; b) berusia pada rentang 15-18 tahun.

Skala identitas etnis yang digunakan dalam penelitian ini adalah skala MEIM (Multigruop Ethnic Identity Measure) yang dikembangkan oleh Phinney (1992). Skala diterjemahkan ke dalam bahasa Indonesia. Skala MEIM ini terdiri dari 12 item yang mewakili 2 dimensi, yaitu dimensi kepemilikan/afirmasi dan eksplorasi. Peneliti menganalisa data menggunakan bantuan software Microsoft Excel 2010 untuk mengetahui hasil dari kedua etnis tersebut.

\section{Hasil}

Hasil penelitian mengenai dimensi identitas etnis dapat dilihat pada tabel dibawah ini:

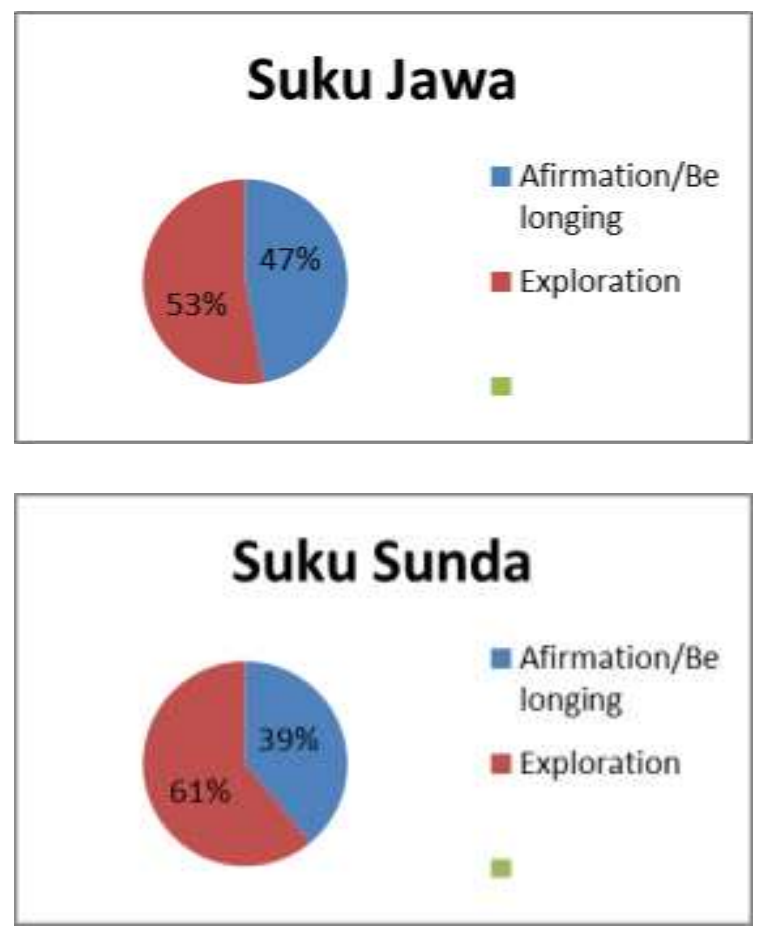

Gambar 1. Persentase dimensi suku Jawa dan suku Sunda 
Tabel 1

Persentase item suku Jawa dan suku Sunda

\begin{tabular}{|c|c|c|c|}
\hline Dimensi & Item & Suku Jawa & Suku Sunda \\
\hline \multirow[t]{7}{*}{$\begin{array}{l}\text { Afirmasi/ } \\
\text { memiliki }\end{array}$} & Memahami latar belakang etnis & $3.33(14 \%)$ & $3.06(13 \%)$ \\
\hline & Bahagia menjadi anggota & $3.93(16 \%)$ & $3.7(15 \%)$ \\
\hline & Rasa memiliki terhadap kelompok & $3.53(14 \%)$ & $3.33(14 \%)$ \\
\hline & Mengerti keanggotaan kelompok & $3.33(13 \%)$ & $3.23(14 \%)$ \\
\hline & Kebanggaan etnis kelompok & $3.76(15 \%)$ & $3.56(15 \%)$ \\
\hline & Keterikatan kuat terhadap kelompok & $3.46(14 \%)$ & $3.4(14 \%)$ \\
\hline & Merasa baik terhadap budaya & $3.53(14 \%)$ & $3.46(15 \%)$ \\
\hline \multirow[t]{5}{*}{ Eksplorasi } & Menghabiskan waktu untuk belajar & $3.06(20 \%)$ & $2.76(18 \%)$ \\
\hline & Aktif dalam organisasi etnis & $2.86(18 \%)$ & $2.86(19 \%)$ \\
\hline & Memikirkan keangotaan kelompok & $2.96(19 \%)$ & $3.33(22 \%)$ \\
\hline & Bicara tentang kelompok & $3.36(22 \%)$ & $3.16(21 \%)$ \\
\hline & Berpartisipasi dalam kegiatan kebudayaan & $3.26(21 \%)$ & $3.03(20 \%)$ \\
\hline
\end{tabular}

Berdasarkan Gambar 1, jika ditinjau dari dimensi identitas etnis, baik suku Jawa maupun suku Sunda lebih tinggi di dimensi rasa memiliki dan rendah di dimensi eksplorasi (Sunda: Afirmasi 39\%, Eksplorasi 61\%; Jawa: Afirmasi 47\%, Eksplorasi 53\%).

Untuk lebih memperdalam mengenai informasi identitas etnis, peneliti selanjutnya melakukan analisis per aitem pertanyaan. Pada skala MEIM ini terdapat 2 dimensi, yakni dimensi afirmasi/memiliki dan eksplorasi. Dimensi afirmasi diwakili oleh aitem nomor 3, 5, 6, 7, 9, 11, dan 12. Sementara dimensi eksplorasi diwakili oleh nomor 1, 2, 4, 8, dan 10.

Berdasarkan tabel diatas, diketahui bahwa hasil analisis persentase suku Jawa paling tinggi pada item 2 yaitu mereka merasa bahagia ketika dirinya menjadi bagian dari anggota etnisnya $(3.93 \%)$. Hal ini berlaku pula bagi suku Sunda, mereka merasa bahagia Sunda menjadi etnisnya meskipun dengan nilai persentase lebih rendah daripada suku Jawa yaitu 3.7\%. Pada item pemahaman tentang keanggotaan dalam kelompok etnisnya, suku Jawa paling rendah (3.33\%) sementara suku Sunda paling rendah di item memahami latar belakang etnisnya $(3.06 \%)$.

Pada suku Jawa, rasa memiliki terhadap kelompok etnis lebih tinggi daripada suku Sunda dengan persentase $3.53 \%$ dan $3.33 \%$. Sama halnya dengan rasa bangga akan etnisnya, suku Jawa lebih tinggi daripada suku Sunda yaitu $3.76 \%$ dan $3.56 \%$. Pada item merasa baik pada budayanya sendiri, suku Jawa sebesar $3.53 \%$ sementara suku Sunda $3.46 \%$. Menariknya, keduanya sama-sama merasakan keterikatan yang kuat terhadap kelompok etnis masing-masing dengan persentase $3.4 \%$.

\section{Diskusi}

Meskipun identitas bersifat universal, konten spesifik dari setiap individu atau identitas kelompok ditentukan secara kultural. Bagaimana seseorang mengidentifikasi dengan identitas tertentu sangat dipengaruhi oleh makna dan asosiasi yang dikaitkan dengan 
budaya atau kelompoknya. Untuk itulah studi terkait identitas etnis dikembangkan.

Konsep identitas etnis dikembangkan Phinney (1990) berdasarkan teori identitas sosial dari Tajfel dan Turner (1986). Phinney menjelaskan identitas etnis sebagai sebuah konstruk multidimensi yang merujuk pada identitas seseorang, atau perasaan diri sebagai anggota dari kelompok etnis tertentu (Phinney, 1990). Disamping teori identitas sosial, konsep identitas etnis dikembangkan menggunakan teori identitas dari Erikson (1968).

Identitas etnis merujuk pada kualitas dari afiliasi seseorang dengan kelompok etnis (Phinney \& Ong, 2007). Identitas etnis dikonseptualisasikan sebagai konstruk multidimensi, perkembangan yang melibatkan proses eksplorasi dari identitas diri seseorang dan komitmen atau perasaan memiliki identitas tersebut (Brown et al., 2014). Dengan demikian identitas etnis adalah pengetahuan tentang kelompok etnis sendiri dan merasa diri sebagai anggota suatu kelompok.

Sebagaimana dikemukakan oleh Phinney (1989), remaja sedang berada dalam tahapan pencarian identitas etnisnya. Pada dimensi eksplorasi, suku Sunda kurang mengeksplorasi budayanya melalui pembelajaran budaya dibandingkan suku Jawa (2.76\%). Suku Jawa sendiri kurang aktif dalam kegiatan-kegiatan yang ada dalam organisasi etnis (2.86\%). Mereka mengeksplorasi budaya melalui pembicaraan-pembicaraan kepada orang lain mengenai etnisnya sementara suku Sunda mengeksplorasi dengan cara memikirkan keanggotaan dalam kelompok etnis. Untuk partisipasi dalam kegiatan kebudayaan, secara berturut-turut suku Jawa dan Sunda sebesar $3.26 \%$ dan $3.03 \%$.

Perkembangan identitas etnis merupakan aspek penting masa remaja. Phinney (1989) mengusulkan model pengembangan identitas etnik untuk anggota semua etnis kelompok. Dalam modelnya seseorang maju melalui tiga tahap. Pertama, identitas etnis yang tidak diperiksa, yaitu ketika individu memiliki pandangan positif atau negatif yang tidak teruji dari kelompok etnis mereka. Kedua, identitas etnis pencarian (atau penjelajahan, yaitu ketika individu telah memulai pencarian apa artinya menjadi anggota kelompok. Ketiga, pencapaian etnis identitas, yaitu ketika individu telah menjelajahi keanggotaan kelompok etnis mereka dan jelas mengenai arti etnisitas dalam kehidupan mereka. Meskipun penghargaan kelompok positif bukanlah bagian dari definisi tahap ketiga, memiliki rasa positif terhadap keanggotaan kelompok etnis sering diharapkan dari individu (Phinney, 1989).

\section{Kesimpulan}

Dari hasil penelitian di atas dapat di simpulkan bahwasannya dalam budaya yang bercampur antara suku Jawa dan Sunda yang terdapat di daerah Ciamis, masing-masing etnis memiliki identitas etnis yang relatif hampir sama nilainya. Kedua etnis ini memiliki rasa kepemilikan yang tinggi terhadap etnisnya namun kedua etnis tersebutpun rendah dalam mengeksplorasi budaya etnisnya.

\section{Saran}

Saran untuk penelitian selanjutnya diharapkan pengambilan data dengan memperbanyak subjek diantara kedua etnis ini penting untuk mendapatkan gambaran yang lebih menyeluruh bagaimana remaja mengeklorasi etnisnya serta rasa memiliki terhadap etnisnya.

Penelitian dapat dikembangkan dengan meneliti secara bersamaan dengan bagaimana identitas etnis dikaitkan dengan penggunaan bahasa, atau nilai (value) dan keyakinan (belief) dari masing-masing kelompok.

\section{Referensi}

Baumeister, R. F., Nathan Dewall, C., Ciarocco, N. J., \& Twenge, J. M. (2005). Social exclusion impairs self-regulation. Journal of Personality and Social Psychology, 88(4), 589-604. https://doi.org/10.1037/00223514.88.4.589

Becker, A. (1990). The role of the school in the maintenance and change of ethnic group affiliation. Human Organization, 49(1), 
48-55.

Brown, C. L. (2009). Heritage Language and Ethnic Identity: A Case Study of KoreanAmerican College Students. International Journal of Multicultural Education, 11(1).

Brown, S. D., Unger Hu, K. A., Mevi, A. A., Hedderson, M. M., Shan, J., Quesenberry, C. P., \& Ferrara, A. (2014). The multigroup ethnic identity measurerevised: measurement invariance across racial and ethnic groups. Journal of Counseling Psychology, 61(1), 154-61. https://doi.org/10.1037/a0034749

Erikson, E. H. (Erik H. (1968). Identity: youth and crisis. New York: W. W. Norton \& Company.

Feuerverger, G. (1991). University Students' Perceptions of Heritage Language Learning and Ethnic Identity Maintenance. Canadian Modern Language Review, 47(4), 660-677. https://doi.org/10.3138/cmlr.47.4.660

Phinney, J. S. (1989). Stages of Ethnic Identity Development in Minority Group Adolescents. The Journal of Early Adolescence, $\quad 9$, 34-49. https://doi.org/10.1177/027243168909100 4

Phinney, J. S. (1990). Ethnic Identity in Adolescents and Adults: Review of Research Article in Psychological Bulletin. Psychological Buletin, 108(3), 499-514. https://doi.org/10.1037/00332909.108.3.499

Phinney, J. S. (1992). The Multigroup Ethnic Identity Measure: A New Scale for Use with Diverse Groups. Journal of Adolescent Research, 7(2), 156-176. https://doi.org/10.1177/074355489272003

Phinney, J. S., \& Ong, A. D. (2007). Conceptualization and Measurement of Ethnic Identity: Current Status and Future Directions. https://doi.org/10.1037/00220167.54.3.271

Phinney, J. S., Romero, I., Nava, M., \& Huang, D. (2001). The role of language, parents, and peers in ethnic identity among adolescents in immigrant families. Journal of Youth and Adolescence, 30(2), 135-153. https://doi.org/10.1023/A:1010389607319

Sanjaya, R. (2012). Perkembangan Dialek di Kabupaten Ciamis. Retrieved October 27, 2018, from http://rizkimasbox.blogspot.com/2012/09/p erkembangan-dialek-di-kabupatenciamis.html

Tajfel, H., \& Turner, J. C. (1986). The Social Identity Theory of Intergroup Behavior. Psychology of Intergroup Relations, 5, $7-$ 24. 